\section{Cureus}

Received 07/05/2017

Review began 07/19/2017

Review ended 08/24/2017

Published 08/30/2017

\section{(C) Copyright 2017}

Vaishya et al. This is an open access article distributed under the terms of the Creative Commons Attribution License CC-BY 3.0., which permits unrestricted use, distribution, and reproduction in any medium, provided the original author and source are credited.

\title{
Is Single-stage Revision Safe Following Infected Total Knee Arthroplasty? A Critical Review
}

\author{
Raju Vaishya ${ }^{1}$, Amit Kumar Agarwal ${ }^{1}$, Sudheer K. Rawat ${ }^{1}$, Harsh Singh ${ }^{1}$, Vipul Vijay ${ }^{1}$ \\ 1. Department of Orthopedics, Indraprastha Apollo Hospital, New Delhi
}

$\square$ Corresponding author: Amit Kumar Agarwal, amitorthopgi@yahoo.co.in

Disclosures can be found in Additional Information at the end of the article

\section{Abstract}

With the improvement in outcomes and modern prosthesis design, total knee arthroplasty (TKA) has now become a commonly performed surgery. It is postulated that a total of $2-5 \%$ of the primary and revision TKA becomes infected every year, requiring a revision procedure which to date is the conventional two-stage revision. The diagnosis and treatment of these periprosthetic infections is a major and challenging task, as it requires precise identification of the pathogen, meticulous debridement, and postoperative rehabilitation. To date, there have been very few studies in existing literature comparing the outcomes of single-stage versus twostage procedure in infected TKA. The aim of the review was to provide the clinicians an insight into the outcome of the single-stage procedure compared to two-stage procedures and to suggest ways to improve the results further. In the following critical review, a total of 669 cases that underwent either a single or two-stage revision for infected TKA were studied. The postoperative functional scores were comparable in most studies during the early postoperative period. Our data supports the use of a single-stage revision surgery in infected TKA as an alternative to a conventional two-stage procedure. However, larger prospective and multicentric trials are required to validate our findings.

Categories: Orthopedics

Keywords: periprosthetic infection, infected total knee arthroplasty, single stage revision, two stage revision

\section{Introduction And Background}

With improved surgical outcomes and modern prosthesis designs, total knee arthroplasty (TKA) has become a popular surgery. It is postulated that a total of $2-5 \%$ of the primary and revision TKAs becomes infected every year [1-4], requiring a revision procedure, which to date is the conventional two-stage revision.

The diagnosis and treatment of these periprosthetic infections is a major and challenging task, as it requires precise identification of the pathogen, an antibiotic strategy, meticulous debridement, careful surgical technique, and postoperative rehabilitation. Nevertheless, this in itself is a cumbersome and time-consuming process. The economic burden of the patient has to be taken into consideration, and the prolonged time to recovery is another big challenge that the orthopedic surgeons face [5]. Some of the other major challenges posed in the management of these infected TKA cases include: the infecting organisms' virulence, type and number of isolates, systemic involvement, the chronicity of illness, soft tissue involvement, and the condition of the available bone stock. 
There is a need for this critical review, as to date there are very few studies in existing literature comparing the outcomes of single-stage versus two-stage procedure in infected TKA. The rate of success of two-stage revision has been reported to be between $72 \%$ and $100 \%$ in eradicating infection and re-establishing a functioning joint [6-11]. The conventional two-stage procedure has proved to be very effective to date, but carries morbidity due to prolonged period of treatment as well as economic overburden. Single-stage revision procedure, though in its nascent stages, has proved to be highly efficacious in selected cases.

This review aims to further study this in detail to provide clinicians an insight into the outcome of the single-stage procedure and suggest ways to improve the results further.

\section{Review}

\section{Two-stage revision TKA}

A two-stage method is the most common technique used for revision TKA worldwide. It involves two steps: the first step is the removal of the infected prosthesis and radical debridement. The resultant gap is filled with an antibiotics-containing cement spacer to maintain the muscle and soft-tissue tension in the knee joint. Articulating spacers are used for few degrees of movement at the knee joint. The second step involves reimplantation after the removal of the antibiotic-impregnated cement spacer at the interval of six to eight weeks (Figures 1-3). 


\section{Cureus}

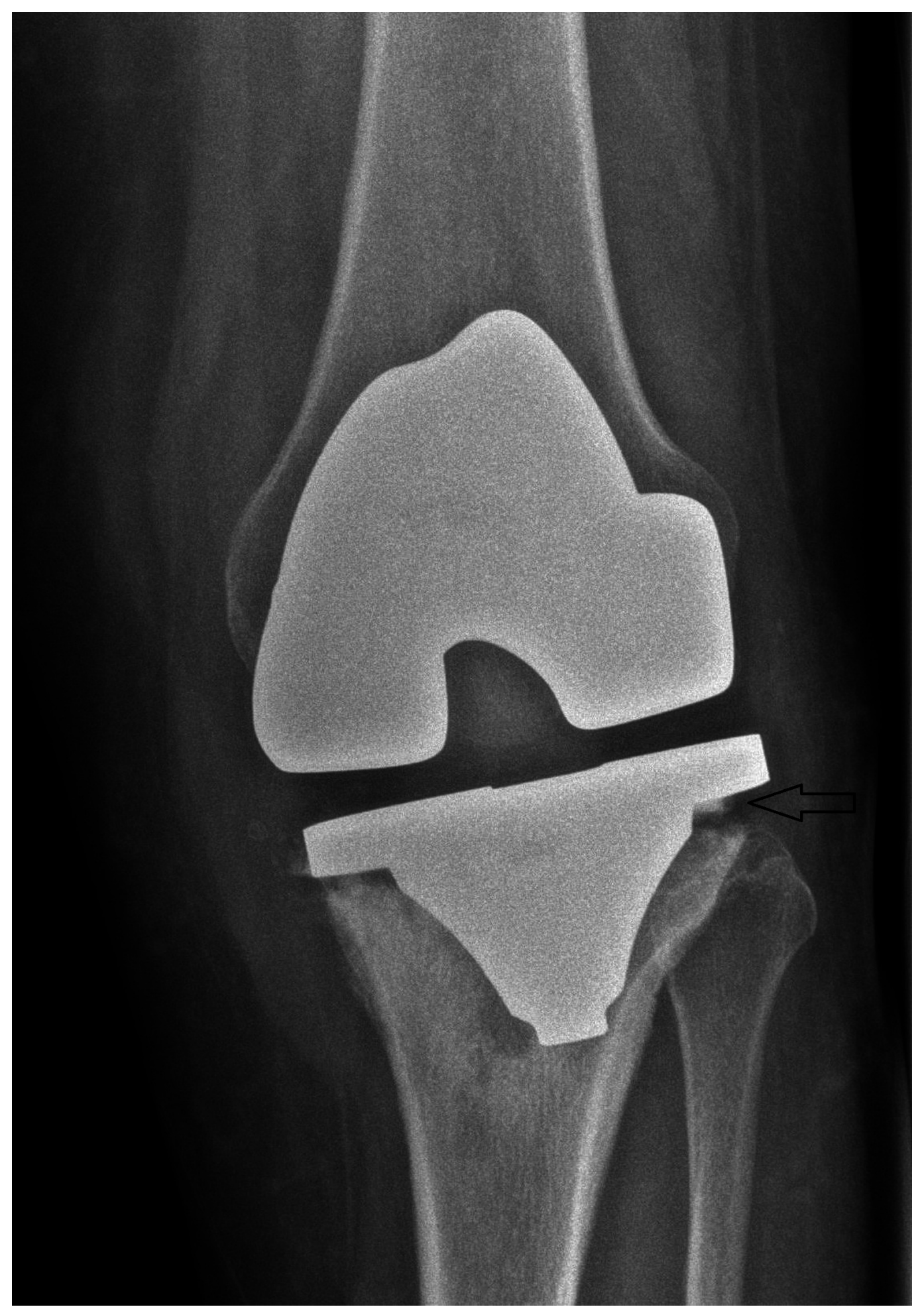

FIGURE 1: Preoperative X-ray of the Left Knee (Anteroposterior View) Showing Loosening of Tibial Component 


\section{Cureus}

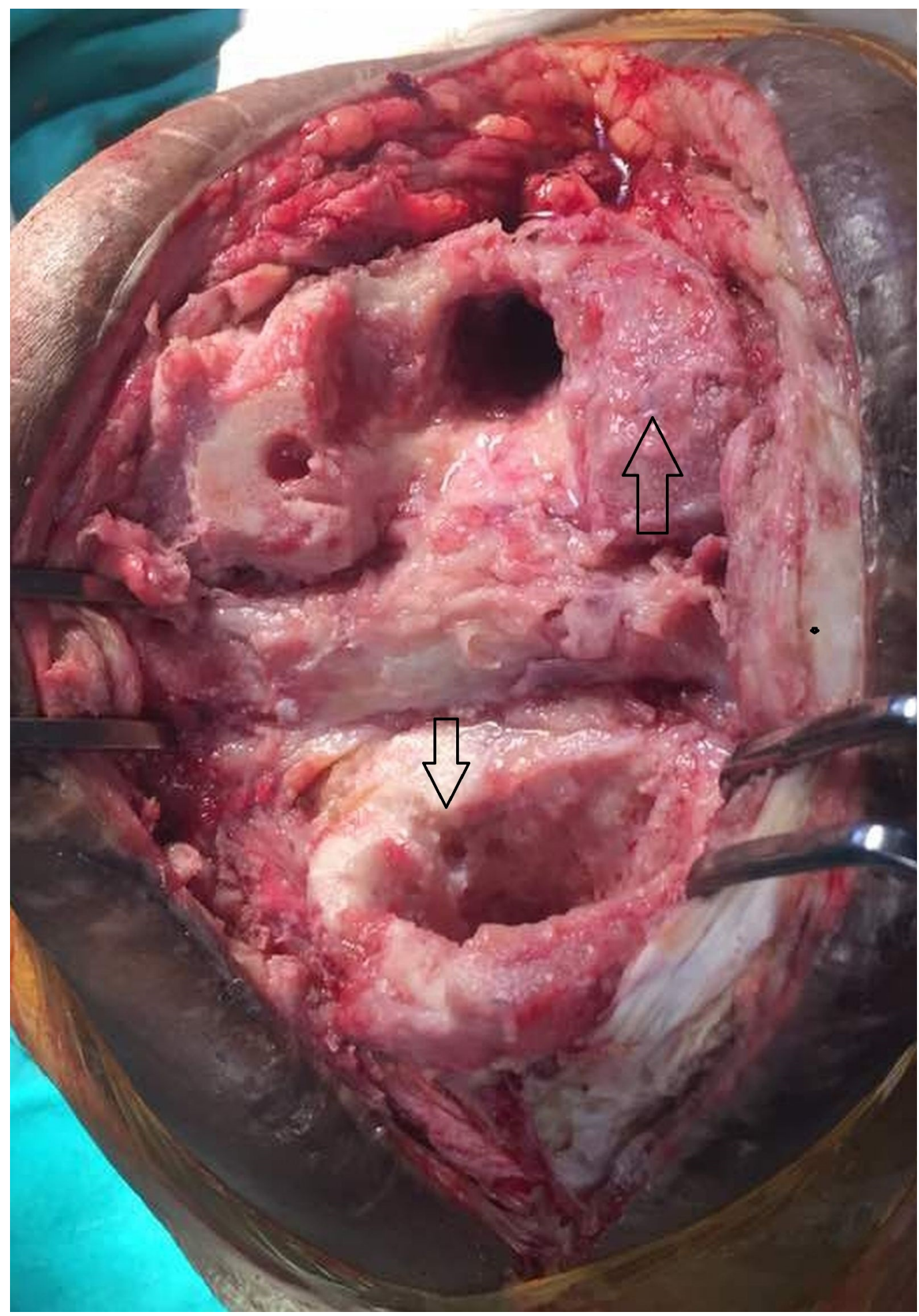

FIGURE 2: Intraoperative Picture After Radical Debridement and Removal of Tibial and Femoral Implants 


\section{Cureus}

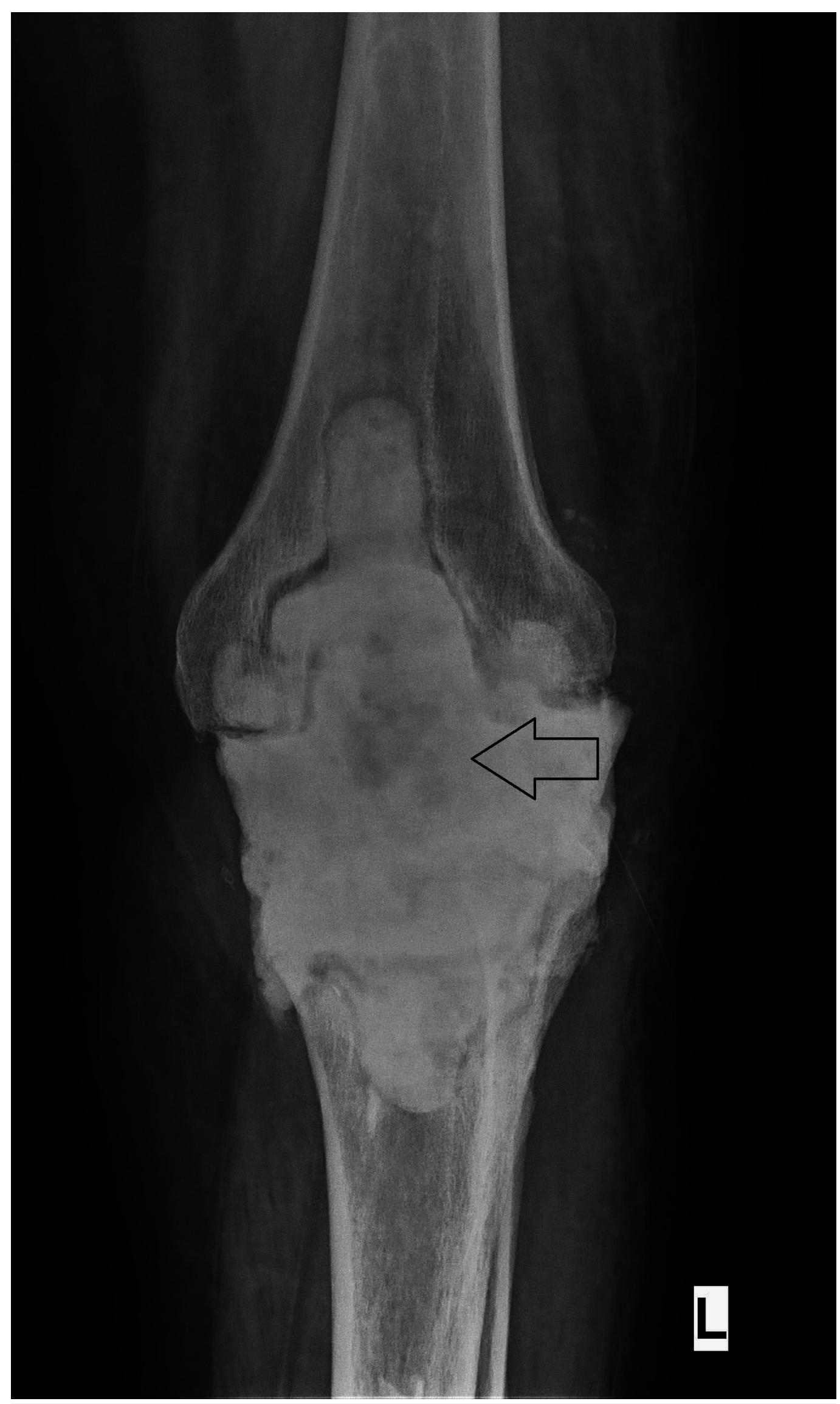

FIGURE 3: X-ray of the Left Knee Showing the Antibioticimpregnated Bone Cement as Spacer after the Removal of 


\section{Cureus}

\section{Infected Implants}

Parenteral antibiotics are adminstered according to culture sensitivity. The inflammatory markers are monitored until they come down to a normal range. After around six to eight weeks, the definitive TKA procedure is performed (Figures 4-5). 


\section{Cureus}

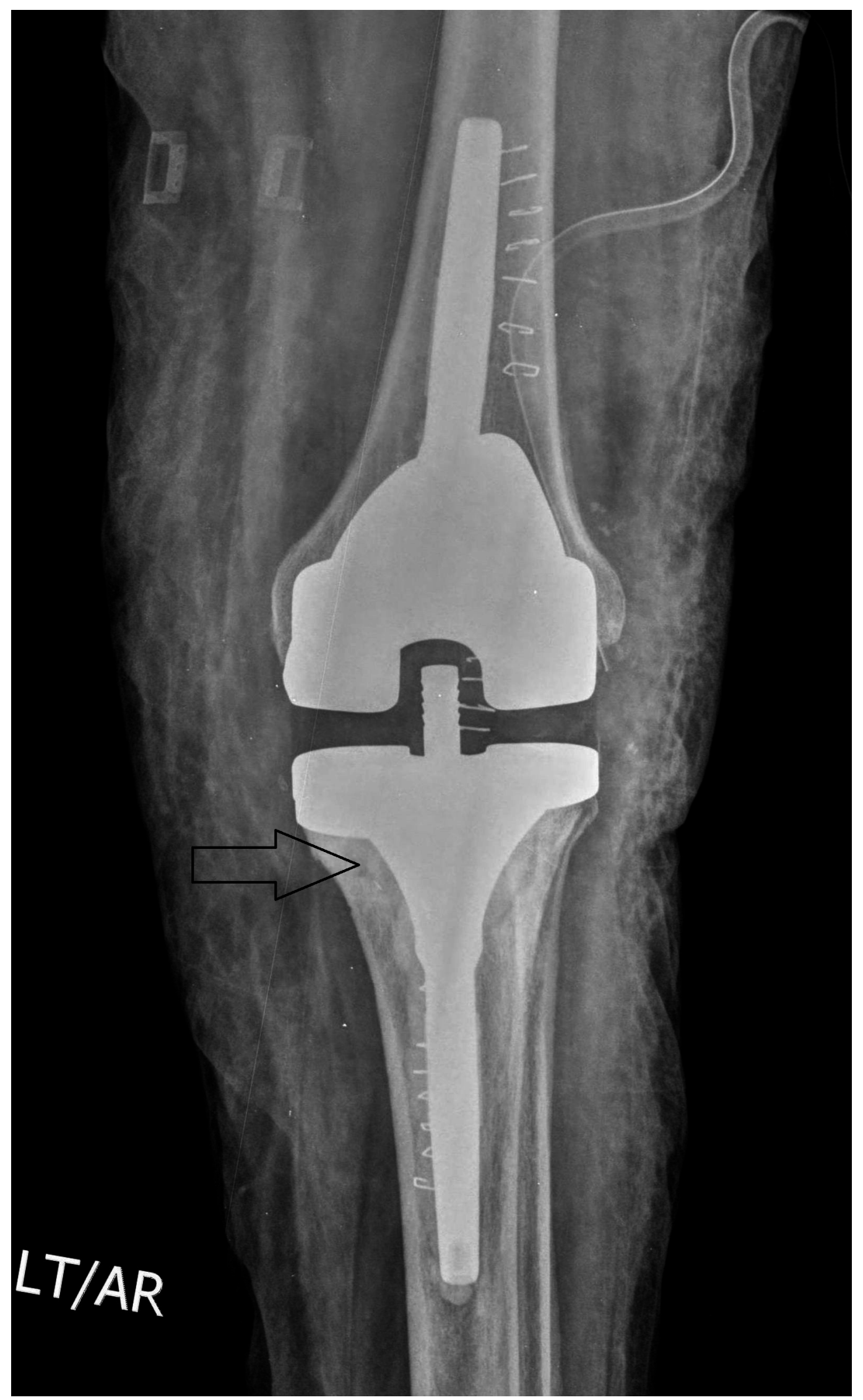

FIGURE 4: Postoperative X-ray (Anteroposterior View) Showing Revision Total Knee Arthroplasty (TKA) 


\section{Cureus}

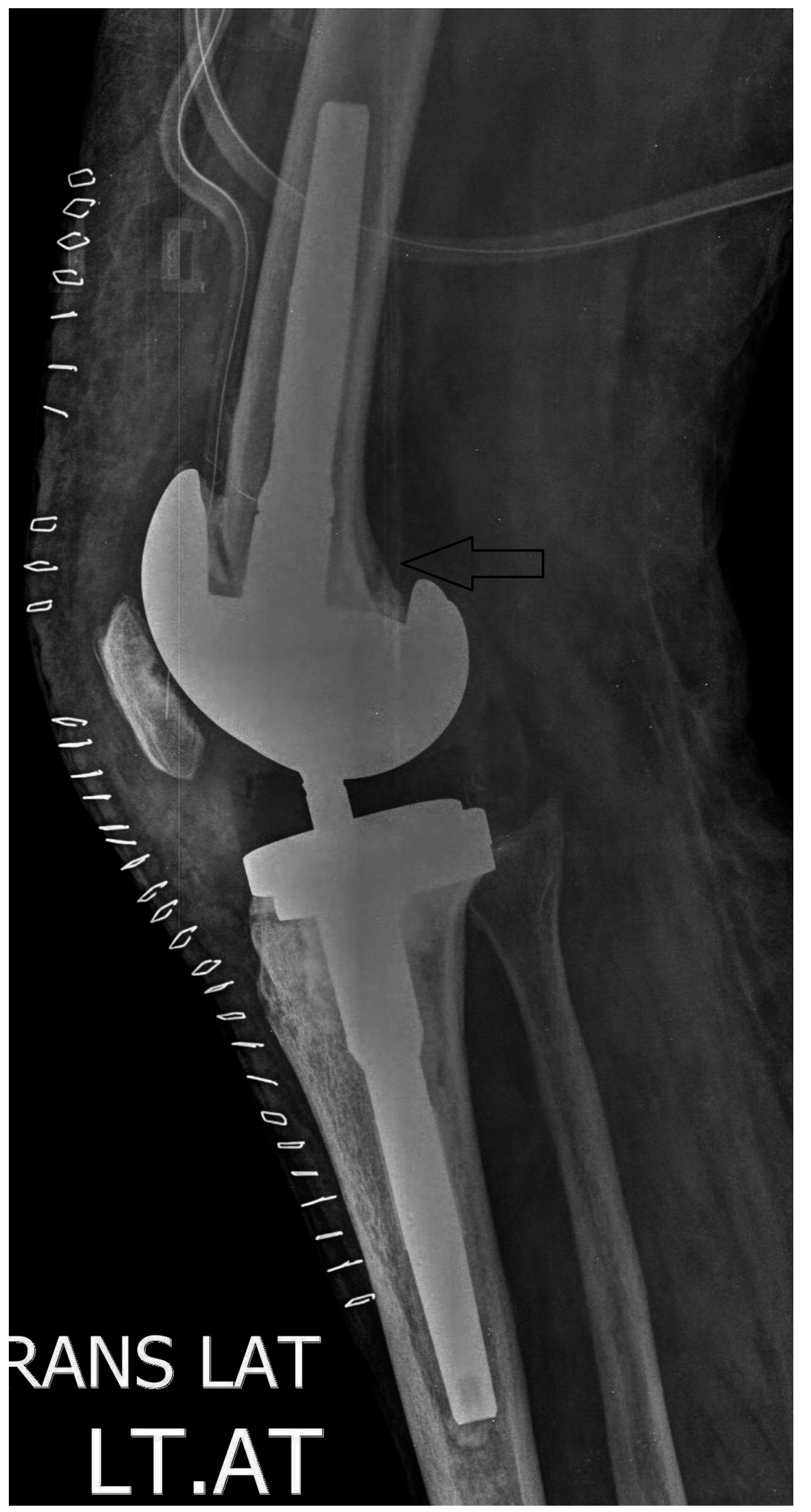




\section{Cureus}

\section{FIGURE 5: Postoperative Lateral View of the Knee Showing Revised Total Knee Arthroplasty (TKA)}

During the single-stage procedure, the revision of the prosthesis is conducted at the same stage after removal of the infected implant. Nowadays, the popularity of the 'one-stage' procedure is increasing due to the disadvantages of the two-stage revision (Table 1).

\section{Two-stage revision}

1 Two major consecutive surgeries are needed

2 Extended hospital stay leads to more comorbidities

3

4
Due to the long interval between two-stage procedure muscles get weak and soft tissue gets contraction

Financial burden due to an extended hospital stay and antibiotics medication

\section{Single-stage revision}

Single surgery

Less comorbidity

Improved functional knee outcome and no risk of soft tissue contraction or muscle weakness

Less financial burden due to single surgery and less duration of hospitalization

\section{TABLE 1: Comparison of Single vs. Two-stage Revision of Infected Total Knee Arthroplasty (TKA)}

Tibrewal, et al. [12], in their cohort of 50 patients with a mean follow-up of 10.5 years, had identified only one true recurrent infection confirmed with a positive microbiological result at the further revision procedure, representing a 98\% success rate. They believed that extensive debridement, identification of the infecting organisms, and proper antibiotic treatment, as directed in discussion with a microbiologist, are the key factors in the success of single-stage revision for the management of an infected TKA. It should gain further acceptance, and they agree with a recent review that advocates its use in selected cases.

In a review by Haddad, et al. [13], out of a total of 102 cases, 28 cases with singlestage revision and 74 cases with two-stage revision were included. The mean follow-up duration of the study was 6.5 years. In the single-stage revision group no reinfection was seen, whereas in two-stage revision, five patients (7\%) developed recurrence of the infection. These patients underwent a further two-stage revision TKA and had their infection controlled at the last follow-up. The Knee Society Score (KSS) was higher in the single-stage group at the twoyear follow-up compared to the two-stage group. There was no evidence of loosening of the prosthesis radiologically at the last follow-up in either group.

In a study by Baker, et al. [14], Patient Reported Outcome Measures (PROMs) for 33 single-stage and 89 two-stage revisions were analyzed in combination with data from the National Joint Registry of England and Wales. Outcomes were measured by various knee scores. No significant statistical difference was found between both groups for any reported outcome measure. The mean Oxford Knee Score (OKS) following surgery was 22.8 for two-stage and 24.9 for singlestage, which is better compared to two-stage revision TKA. The mean EuroQol five-dimension questionnaire (EQ-5D) index following surgery was 0.495 for single and 0.473 for two-stage. Patients reporting Excellent/Very good/Good satisfaction levels were similar in both the groups. 
In total, 66\% single and 60\% two-stage operations were rated 'successful'. This study did not find any demonstrable benefit of one technique over the other using a variety of PROMs. It did not discuss the rate of reinfection, and a third parameter for the study was subjective. There was a marginal benefit in all the three parameters used in the study of single-stage compared to two-stage revision TKA.

Klatte, et al. [15] in their study between 2001-11 suggested that fungal periprosthetic joint infections are rare but can lead to chronic complications. They evaluated the results of their single-stage revision technique. A total of 14 patients were treated for a periprosthetic fungal infection. Unfortunately, two patients died of unrelated causes. Out of four cases of TKA, one patient had delayed wound healing and subsequently underwent exploration without revision of the components. There was no sign of infection. This patient suffered a periprosthetic femoral fracture 29 months postoperatively. At this revision, no bacterial or fungal growth was detected. In another patient with a TKA, further infection with Candida parapsilosis required revision with a second single-stage two months after the surgery. This patient, who is immunocompromised as a result of steroid use for more than 15 years for chronic obstructive lung disease, also has diabetes mellitus and developed recurrent necrosis of the skin, requiring soft-tissue reconstruction on two occasions. One year later, he presented with a sinus around the knee, and on aspiration, intraoperative samples showed growth of Staphylococcus epidermidis. A third single-stage exchange revision was undertaken, and there have been no further signs of infection for more than 1.7 years. Thus, at a mean follow-up of seven years, there has been one further infection. A single-stage revision following fungal periprosthetic infection is feasible, with an acceptable rate of a satisfactory outcome.

Gulhane, et al. [16] in a review reported a 97\% success rate for single-stage revision performed at their institute, after a minimum follow-up of two years. They used a technique similar to the one used by Tibrewal, et al. with cement loaded with vancomycin and tobramycin, and allograft. However, their study did not mention any specific sample size, and not much information was included regarding the functional recovery or cost analysis. The gold standard procedure in their institution is a two-stage revision. They concluded that single-stage revision is a preferred option and can be used judiciously for appropriate patients.

\section{Single-stage revision TKA}

Mortazavi, et al. [17] in their retrospective cohort study of 117 cases stated that the mean follow-up period was 3.8 years. The rate of reinfection was $28 \%$. The common organism isolated was Staphylococcus aureus, requiring revision surgery. The success rate of singlestage revision TKA was $72 \%$. It needs longer follow-up to validate its result.

Von Foster, et al. [18] in their study had 118 cases who underwent single-stage revision TKA using specific antibiotic-loaded cement. This study had a success rate of $73 \%$, similar to Mortazavi, et al. It had a long follow-up, averaging 10.5 years. Seventy-six cases were cured as a result of this single-stage revision TKA. The reinfection rate was $27 \%$, which later on went to revision by the two-stage procedure. Of these, 20 cases of one-stage revision TKA failed in the treatment of periprosthetic infections after TKA.

In a case series of 12 cases of revision TKA by Parkinson, et al. [19], there were zero rates of reinfection after single-stage revision of infected TKA, with a success rate of $100 \%$. However, it had only 12 cases, which was a very small group, and the follow-up was conducted after a short period of only two years. In order to consider its results, long follow-up is needed.

Postoperative knee functional score was not measured in this study. While knowing the reinfection rate at the final outcome is indeed necessary, knowing the functional knee score as well is very important. 


\section{Cureus}

Buechel, et al. [20] had a case series of 22 patients of infected TKAs treated by a single-stage revision. Though the number was small, it had a long follow-up period of mean 10.2 years. Of these, $90.9 \%$ were free of recurrent infection. The rate of reinfection was $9.1 \%$, which is similar to other studies of single-stage revision. They performed radical debridement with normal saline and betadine irrigation. Their outcome was based on two parameters: reinfection and KSS. Knee scores averaged 79.5 , with $85.7 \%$ good or excellent results.

Singer, et al. [21] retrospectively reviewed a prospective study of 63 cases of single-stage revisions between 2004-6. All cases were treated with microorganism-specific antibiotics locally and systemically, excluding patients with methicillin-resistant Staphylococcus aureus (MRSA), methicillin-resistant Staphylococcus epidermidis (MRSE), or unknown microorganisms. The patients' follow-ups were conducted every three months where the OKS and KSS were assessed. The minimum follow-up was 24 months. The chances of infection control were influenced by the duration of infection. The mean KSS at two years after surgery was 72 points, the mean Knee Society function score was 71 points, and the mean Oxford knee score was 27 points with a success rate of $95 \%$ and a reinfection rate of $5 \%$. However, this indicates that follow-up was of a three-year duration, which is a short follow-up period. This result was based on reinfection and postoperative knee functional score.

In the following critical review, a total of 669 cases were studied, which underwent either a single or two-stage revision for infected TKA (Table 2).

\begin{tabular}{|c|c|c|c|c|c|c|c|c|c|}
\hline Sr.no & $\begin{array}{l}\text { Name of } \\
\text { study }\end{array}$ & $\begin{array}{l}\text { Study } \\
\text { type }\end{array}$ & $\begin{array}{l}\text { No. Of } \\
\text { cases }\end{array}$ & $\begin{array}{l}\text { Follow- } \\
\text { up } \\
\text { (mean) } \\
\text { yrs }\end{array}$ & $\begin{array}{l}\text { Commonly isolated } \\
\text { organism }\end{array}$ & $\begin{array}{l}\text { Reinfection } \\
\text { rate }\end{array}$ & $\begin{array}{l}\text { Antibiotics used in } \\
\text { cement }\end{array}$ & $\begin{array}{l}\text { Revision } \\
\text { after } \\
\text { one } \\
\text { stage }\end{array}$ & $\begin{array}{l}\text { Success } \\
\text { rate } \%\end{array}$ \\
\hline 1 & $\begin{array}{l}\text { Tibrewal, } \\
\text { et al. [12] } \\
(2014)\end{array}$ & $\begin{array}{l}\text { Case } \\
\text { series }\end{array}$ & 50 & 10.5 & Staphylococcus Aureus & $8 \%$ & $\begin{array}{l}\text { Cement + sensitive } \\
\text { antibiotic }\end{array}$ & $2 \%$ & $98 \%$ \\
\hline 2 & $\begin{array}{l}\text { Haddad, et } \\
\text { al. [13] } \\
\text { (2014) }\end{array}$ & Cohort & $\begin{array}{l}102 \\
1 \text { st } 28 \\
\text { 2nd } \\
74\end{array}$ & 6.5 & $\begin{array}{l}\text { Coagulase negative } \\
\text { Staphylococcus Aureus } \\
(33 \%)\end{array}$ & $\begin{array}{l}1 \text { st-0\% } \\
2 \text { nd- } 7 \%\end{array}$ & $\begin{array}{l}1 \mathrm{gm} \text { vancomycin and } \\
1 \mathrm{gm} \text { gentamycin in } \\
40 \mathrm{gm} \text { of Placos }\end{array}$ & - & $100 \%$ \\
\hline 3 & $\begin{array}{l}\text { Baker, et } \\
\text { al. [14] } \\
(2013)\end{array}$ & $\begin{array}{l}\text { Retro } \\
\text { Cohort }\end{array}$ & $\begin{array}{l}195 \\
1 \text { st-33 } \\
\text { 2nd- } \\
89\end{array}$ & 7mth & NR & NR & $\begin{array}{l}\text { Cement + specific } \\
\text { antibiotics }\end{array}$ & NR & $66 \%$ \\
\hline 4 & $\begin{array}{l}\text { Klatte, et } \\
\text { al. [15] } \\
(2014)\end{array}$ & $\begin{array}{l}\text { Case } \\
\text { series }\end{array}$ & 4 & 7 & $\begin{array}{l}\text { Candida Parapsilosis and } \\
\text { Staph Epidermidis }\end{array}$ & $25 \%$ & $\begin{array}{l}10 \% \text { of admixture } \\
\text { (vancomycin, } \\
\text { clindamycin and } \\
\text { gentamycin) }\end{array}$ & $25 \%$ & $75 \%$ \\
\hline 5 & $\begin{array}{l}\text { Gulhane, } \\
\text { et al. [16] } \\
(2012)\end{array}$ & $\begin{array}{l}\text { Retro } \\
\text { cohort }\end{array}$ & - & 2.5 & NR & - & $\begin{array}{l}\text { Antibiotic inpregnated } \\
\text { cement gentamycin } \\
+ \text { specific antibiotic } \\
\text { systemic }\end{array}$ & - & $97 \%$ \\
\hline 6 & $\begin{array}{l}\text { Mortazavi, } \\
\text { et al. [17] }\end{array}$ & $\begin{array}{l}\text { Retro } \\
\text { cohort }\end{array}$ & 117 & 3.8 & $\begin{array}{l}\text { Staph aureus (27\%), Staph. } \\
\text { epidermidis (16\%), Group B }\end{array}$ & $28 \%$ & Antibiotic cement & $28 \%$ & $72 \%$ \\
\hline
\end{tabular}




\section{Cureus}

\begin{tabular}{|c|c|c|c|c|c|c|c|c|c|}
\hline & (2011) & & & & Streptococci $(4.6 \%)$ & & & & \\
\hline 7 & $\begin{array}{l}\text { von } \\
\text { Foerster, } \\
\text { et al. [18] } \\
\text { (1991) }\end{array}$ & $\begin{array}{l}\text { Retro } \\
\text { cohort }\end{array}$ & 104 & 10.5 & NR & $27 \%$ & $\begin{array}{l}\text { Antibiotic containing } \\
\text { cement }\end{array}$ & $27 \%$ & $73 \%$ \\
\hline 8 & $\begin{array}{l}\text { Buechel, } \\
\text { et al. [20] } \\
(2004)\end{array}$ & $\begin{array}{l}\text { Case } \\
\text { series }\end{array}$ & 22 & 10.2 & NR & $10 \%$ & $\begin{array}{l}\text { Specific antibiotic + } \\
\text { cement }\end{array}$ & $10 \%$ & $90.9 \%$ \\
\hline 9 & $\begin{array}{l}\text { Parkinson, } \\
\text { et al. [19] } \\
\text { (2011) }\end{array}$ & $\begin{array}{l}\text { Case } \\
\text { series }\end{array}$ & 12 & 2 & NR & $0 \%$ & Antibiotic cement & $0 \%$ & $100 \%$ \\
\hline 10 & $\begin{array}{l}\text { Singer, et } \\
\text { al. [21] } \\
\text { (2012) }\end{array}$ & $\begin{array}{l}\text { Retro } \\
\text { cohort }\end{array}$ & 63 & 3 & NR & $5 \%$ & Antibiotic cement & $5 \%$ & $95 \%$ \\
\hline
\end{tabular}

\section{TABLE 2: Critical Review of the Study}

NR - not recorded

Most reviews done to date have focused on validating the usefulness versus futility of the single-stage procedure. In the following review, many more parameters were incorporated and finer details were noted (Table 3). 


\section{Cureus}

\begin{tabular}{|c|c|c|c|}
\hline SR.NO & Study & Functional score & Results \\
\hline 1 & $\begin{array}{l}\text { Haddad, et } \\
\text { al. [13] }\end{array}$ & Knee Society Score & $\begin{array}{l}\text { KSS-56 points improvement in single stage group, } 45 \text { points } \\
\text { improvement in two-stage group (at two-year follow-up) }\end{array}$ \\
\hline 2 & $\begin{array}{l}\text { Tibrewal, et } \\
\text { al. [12] }\end{array}$ & Oxtord Knee Score & 20 points improvement (OKS) at one-year follow-up \\
\hline 3 & $\begin{array}{l}\text { Kratte, et al. } \\
\text { [15] }\end{array}$ & $\begin{array}{l}\text { Hospital for Special Surgery } \\
\text { Knee Score }\end{array}$ & 24 points improvement (HSS) at mean follow-up of $/$ years \\
\hline 4 & $\begin{array}{l}\text { Gulhane, et } \\
\text { al. [16] }\end{array}$ & $\begin{array}{l}\text { Post operation five-year } \\
\text { infection-free rate. }\end{array}$ & - \\
\hline 5 & $\begin{array}{l}\text { Baker, et al. } \\
{[14]}\end{array}$ & $\begin{array}{l}\text { Patient reported outcome } \\
\text { measures, Oxford Knee Score }\end{array}$ & 24.9 (single-stage group), 22.8 (two-stage group)-OKS \\
\hline 6 & $\begin{array}{l}\text { Mortazavi, } \\
\text { et al. [17] }\end{array}$ & NR & $\mathrm{NR}$ \\
\hline 7 & $\begin{array}{l}\text { von } \\
\text { Foerster, et } \\
\text { al. [18] }\end{array}$ & NR & NR \\
\hline 8 & $\begin{array}{l}\text { Buecnel, et } \\
\text { al. [20] }\end{array}$ & Knee Society Score. & KSS scores averaged 79.5 \\
\hline 9 & $\begin{array}{l}\text { Parkinson, } \\
\text { et al. [19] }\end{array}$ & NR & NR \\
\hline 10 & $\begin{array}{l}\text { Singer, et } \\
\text { al. [21] }\end{array}$ & $\begin{array}{l}\text { Knee Society Score, Oxford } \\
\text { Knee Score }\end{array}$ & score was 71 points \\
\hline
\end{tabular}

\section{TABLE 3: Early Postoperative Knee Scores in Various Studies}

OKS - Oxford Knee Score, HSS - Hospital for Special Surgery, NR - not recorded, KSS - Knee Society Score.

Most studies did not note any significant difference between the two procedures. The postoperative functional scores were comparable in most studies during the early postoperative period. Selection of the right case and meticulous preoperative planning, coupled with the correct operative technique can result in equally good outcomes, following a single-stage revision procedure for infected TKA. It is noted in most studies of relevance that some reoperations are directly linked to the success or failure of the procedure [22-25]. Good surgical practices such as adequate debridement, chlorohexidine packing for 30 minutes followed by redraping, and use of a fresh set of instruments can harvest promising results [26-30]. It is recommended that a total of 10 percent of the antibiotic admixture per 40 gram of cement is used. However, some surgeons prefer to use a higher concentration of antibiotics in cement. A postoperative antibiotic period ranging from 7-12 weeks was used in most of the procedures [31-36]. After these recommendations from the preliminary data and early experience, it is concluded that a single-stage revision procedure for infected TKA can be a safe and costeffective measure when performed in the cases with specific indication. This can also be an effective alternative to the conventional two-stage procedure. However, further studies need to 
be conducted regarding this concern.

The drawback of the review is that it is hard to compare between various outcome measures as different studies have used different parameters. Very few studies are available in literature, hence limiting the validity.

\section{Conclusions}

The two-stage revision TKA procedure is considered the gold standard for the management of infected TKA. However, this systematic review demonstrates a much larger body of evidence to suggest the use of single-stage procedure over two-stage procedure. Our data supports the use of single-stage revision surgery in infected TKA cases as an alternative to a two-

stage procedure, in carefully selected patients. None of the studies described here offer definitive evidence to support either technique. Multiple prospective and multicenter trials are needed to validate our findings.

\section{Additional Information \\ Disclosures}

Conflicts of interest: In compliance with the ICMJE uniform disclosure form, all authors declare the following: Payment/services info: All authors have declared that no financial support was received from any organization for the submitted work. Financial relationships: All authors have declared that they have no financial relationships at present or within the previous three years with any organizations that might have an interest in the submitted work. Other relationships: All authors have declared that there are no other relationships or activities that could appear to have influenced the submitted work.

\section{References}

1. Patel A, Pavlou G, Mújica-Mota RE, et al.: The epidemiology of revision total knee and hip arthroplasty in England and Wales- a comparative analysis with projections for the United States. A study using the National Joint Registry dataset. Bone Joint J. 2015, 97:1076-81. 10.1302/0301-620X.97B8.35170

2. Kurtz SM, Lau E, Schmier J, et al.: Infection burden for hip and knee arthroplasty in the United States. J Arthroplasty. 2008, 23:984-91. 10.1016/j.arth.2007.10.017

3. Lenza, M, Ferraz SB, Viola DCM, et al.: Surgical site infection after primary hip and knee arthroplasty: a cohort study using a hospital database. Einstein (Sao Paulo). 2013, 11:197-202. 10.1590/S1679-45082013000200011

4. Tanner J, Padley W, Kiernan M, et al.: A benchmark too far: findings from a national survey of surgical site infection surveillance. J Hosp Infect. 2013, 83:87-91. 10.1016/j.jhin.2012.11.010

5. Lavernia C, Lee DJ, Hernandez VH: The increasing financial burden of knee revision surgery in the United States. Clin Orthop Relat Res. 2006, 446:221-6.

10.1097/01.blo.0000214424.67453.9a

6. Haddad FS, Masri BA, Campbell D, et al.: The PROSTALAC functional spacer in two-stage revision for infected knee replacements. Prosthesis of antibiotic-loaded acrylic cement. J Bone Joint Surg Br. 2000, 82:807-12.

7. Laffer RR, Graber P, Ochsner PE, et al.: Outcome of prosthetic knee-associated infection: evaluation of 40 consecutive episodes at a single centre. Clin Microbiol Infect. 2006, 12:4339. 10.1111/j.1469-0691.2006.01378.x

8. Leone JM, Hanssen AD: Management of infection at the site of a total knee arthroplasty . J Bone Joint Surg Am. 2005, 87:2335-48.

9. Pitto RP, Castelli CC, Ferrari R, et al.: Pre-formed articulating knee spacer in two-stage revision for the infected total knee arthroplasty. Int Orthop. 2005, 29:305-308. 10.1007/s00264-005-0670-6

10. Zimmerli W, Trampuz A, Ochsner PE: Prosthetic joint infections. N Engl J Med. 2004, 
351:1645-54. 10.1056/NEJMra040181

11. Mortazavi SM, Vegari D, Ho A, et al.: Two-stage exchange arthroplasty for infected total knee arthroplasty: predictors of failure. Clin Orthop Relat Res. 2011, 469:3049-54. 10.1007/s11999011-2030-8

12. Tibrewal S, Malagelada F, Jeyaseelan L, et al.: Single-stage revision for the infected total knee replacement. Bone Joint J. 2014, 96:759-64. 10.1302/0301-620X.96B6.33086

13. Haddad FS, Sukeik M, Alazzawi S: Is single-stage revision according to a strict protocol effective in treatment of chronic knee arthroplasty infections?. Clin Orthop Relat Res. 2015, 473:8-14. 10.1007/s11999-014-3721-8

14. Baker P, Petheram TG, Kurtz S, et al.: Patient reported outcome measures after revision of the infected TKR: comparison of single versus two-stage revision. Knee Surg Sports Traumatol Arthrosc. 2013, 21:2713-20. 10.1007/s00167-012-2090-7

15. Klatte TO, Kendoff D, Kamath AF, et al.: Single-stage revision for fungal peri-prosthetic joint infection: a single-centre experience. Bone Joint J. 2014, 96:492-6. 10.1302/0301-

620X.96B4.32179

16. Gulhane S, Vanhegan IS, Haddad FS: Single stage revision: regaining momentum. J Bone Joint Surg Br. 2012, 94:120-2. 10.1302/0301-620X.94B11.30746

17. Mortazavi SM, Schwartzenberger J, Austin MS, et al.: Revision total knee arthroplasty infection: incidence and predictors. Clin Orthop Relat Res. 2010, 468:2052-9. 10.1007/s11999010-1308-6

18. von Foerster G, Klüber D, Käbler U: Mid- to long-term results after treatment of 118 cases of periprosthetic infections after knee joint replacement using one-stage exchange surgery [Article in German]. Orthopade. 1991, 20:244-52.

19. Parkinson RW, Kay PR, Rawal A: A case for one-stage revision in infected total knee arthroplasty?. Knee. 2011, 18:1-4. 10.1016/j.knee.2010.04.008

20. Buechel FF: The infected total knee arthroplasty: just when you thought it was over . J Arthroplasty. 2004, 19:51-5. 10.1016/j.arth.2004.03.001

21. Singer J, Merz A, Frommelt L, et al.: The high rate of infection control with the one-stage revision of septic knee prostheses excluding MRSA and MRSE. Clin Orthop Relat Res. 2012, 470:1461-71. 10.1007/s11999-011-2174-6

22. Blom AW, Brown J, Taylor AH, et al.: Infection after total knee arthroplasty. J Bone Joint Surg Br. 2004, 86:688-91. 10.1302/0301-620X.86B5.14887

23. Bongartz T, Halligan CS, Osmon DR, et al.: Incidence and risk factors of prosthetic joint infection after total hip or knee replacement in patients with rheumatoid arthritis. Arthritis Rheum. 2008, 59:1713-1720. 10.1002/art.24060

24. Bradbury T, Fehring T, Taunton M, et al.: The fate of acute methicillin-resistant Staphylococcus aureus periprosthetic knee infections treated by open debridement and retention of components. J Arthroplasty. 2009, 24:101-104. 10.1016/j.arth.2009.04.028

25. Fehring TK, Griffin WL: Revision of failed cementless total knee implants with cement . Clin Orthop Relat Res. 1998, 356:34-38.

26. Goldberg VM, Figgie MP, Figgie HE 3rd, et al.: The results of revision total knee arthroplasty . Clin Orthop Relat Res. 1988, 226:86-92.

27. Johnson DP, Bannister GC: The outcome of infected arthroplasty of the knee . J Bone Joint Surg Br. 1986, 68:289-91.

28. Peters CL, Hennessey R, Barden RM, et al.: Revision total knee arthroplasty with a cemented posterior-stabilized or constrained condylar prosthesis: a minimum 3-year and average 5-year follow-up study. J Arthroplasty. 1997, 12:896-903. 10.1016/S0883-5403(97)90159-5

29. Poss R, Thornhill TS, Ewald FC, et al.: Factors influencing the incidence and outcome of infection following total joint arthroplasty. Clin Orthop Relat Res. 1984, 182:117-126.

30. Pulido L, Ghanem E, Joshi A, et al.: Periprosthetic joint infection: the incidence, timing, and predisposing factors. Clin Orthop Relat Res. 2008, 466:1710-15. 10.1007/s11999-008-0209-4

31. Wymenga AB, Horn JR, Theeuwes A, et al.: Perioperative factors associated with septic arthritis after arthroplasty. Prospective multicenter study of 362 knees and 2651 hip operations. Acta Orthop Scand. 1992, 63:665-71. 10.1080/17453679209169732

32. Wilson MG, Kelley K, Thornhill TS: Infection as a complication of total knee-replacement arthroplasty. Risk factors and treatment in sixty-seven cases. J Bone Joint Surg Am. 1990, 72:878-83.

33. Stuart MJ, Larson JE, Morrey BF: Reoperation after condylar revision total knee arthroplasty. 


\section{Cureus}

Clin Orthop Relat Res. 1993, 286:168-73.

34. Sierra RJ, Cooney WP, Pagnano MW, et al.: Reoperations after 3200 revision TKAs: rates, etiology, and lessons learned. Clin Orthop Relat Res. 2004, 425:200-06. 10.1097/01.blo.0000138094.86911.55

35. Segawa H, Tsukayama DT, Kyle RF, et al.: Infection after total knee arthroplasty. A retrospective study of the treatment of eighty-one infections. J Bone Joint Surg Am. 1999, 81:1434-45.

36. Saleh K, Olson M, Resig S, et al.: Predictors of wound infection in hip and knee joint replacement: results from a 20-year surveillance program. J Orthop Res. 2002, 20:506-15. 10.1016/S0736-0266(01)00153-X 